Tropical Journal of Pharmaceutical Research, April 2009; 8 (2): 117-125

(C) Pharmacotherapy Group,

Faculty of Pharmacy, University of Benin,

Benin City, 300001 Nigeria.

All rights reserved.

Research Article

Available online at http://www.tjpr.org

\title{
Anticonvulsant Activity of Carissa carandas Linn. Root Extract in Experimental Mice
}

\author{
Karunakar Hegde ${ }^{1^{*}}$, Shalin P Thakker ${ }^{2}$, Arun B Joshi ${ }^{3}$, CS Shastry ${ }^{1}$, KS \\ Chandrashekhar ${ }^{3}$ \\ ${ }^{1}$ Department of Pharmacology, Srinivas College of Pharmacy, Valachil, Post-Parangepete, Mangalore-574 143 , \\ Karnataka, ${ }^{2}$ Department of Pharmaceutics, Soniya Education Trust's College of Pharmacy, S. R. Nagar, Dharwad- \\ 580 002, Karnataka, ${ }^{3}$ Department of Pharmacognosy, N. G. S. M. Institute of Pharmaceutical Sciences, Mangalore- \\ 574 160, Karnataka, India.
}

\begin{abstract}
Purpose: The aim of the present study was to investigate anticonvulsant effect of the ethanolic extract of the roots of Carissa carandas (ERCC) on electrically and chemically induced seizures.

Methods: The ethanolic extract of the roots of C. carandas (100, 200 and $400 \mathrm{mg} / \mathrm{kg}$, i.p.) was studied for its anticonvulsant effect on maximal electroshock-induced seizures and pentylenetetrazole-, picrotoxin-, bicuculline- and N-methyl-dl-aspartic acid-induced seizures in mice. The latency of tonic convulsions and the number of animals protected from tonic convulsions were noted.

Results: ERCC (100-400 mg/kg) significantly reduced the duration of seizures induced by maximal electroshock (MES). However, only 200 and $400 \mathrm{mg} / \mathrm{kg}$ of the extract conferred protection (25 and 50\%, respectively) on the mice. The same doses also protected animals from pentylenetetrazole-induced tonic seizures and significantly delayed the onset of tonic seizures produced by picrotoxin and N-methyl-dl-aspartic acid. The extract had no effect on bicuculline-induced seizures.

Conclusion: The data suggest that the ethanolic root extract of $C$. carandas may produce its anticonvulsant effects via non-specific mechanisms since it reduced the duration of seizures produced by maximal electroshock as well as delayed the latency of seizures produced by pentylenetetrazole and picrotoxin.
\end{abstract}

Keywords: Carissa carandas, Ethanol extract, Anticonvulsant activity, Convulsion, Seizures, Mice.

*Corresponding author: Email: khegde_sh2003@yahoo.co.in; Tel: +91-824-2274722; Fax: +91-824-2274725 


\section{Introduction}

Epilepsy is a major neurological disorder and up to $5 \%$ of the world population develops epilepsy in their lifetime ${ }^{1}$. The current therapy of epilepsy with modern antiepileptic drugs is associated with side effects, dose-related and chronic toxicity, as well as teratogenic effects, and approximately $30 \%$ of the patients continue to have seizures with current antiepileptic drugs therapy ${ }^{2-4}$. Traditional systems of medicine are popular in developing countries and up to $80 \%$ of the population relies on traditional medicines or folk remedies for their primary health care need ${ }^{5}$. Medicinal plants are believed to be an important source of new chemical substances with potential therapeutic effects ${ }^{6}$. Several plants used for the treatment of epilepsy in different systems of traditional medicine have shown activity when tested in modern bioassays for the detection of anticonvulsant activity and many such plants are yet to be scientifically investigated.

Carissa carandas Linn. (Syn. Carissa congesta Wight) is a large dichotomously branched evergreen shrub with short stem and strong thorns in pairs, belonging to family Apocynaceae. The plant is native and common throughout much of India, Sri Lanka, Java, Malaysia, Myanmar and Pakistan. In traditional system of medicine, the plant is used as an anthelmintic, astringent, appetizer, antipyretic, in biliary, stomach disorders, rheumatism and disease of the brain ${ }^{8}$. Earlier studies have shown that the extract of the plant possesses cardiotonic, antipyretic and antiviral activity ${ }^{9-11}$. Various cardiac glycosides, a triterpenoidal constituent carissone and $\beta$-sitosterol were reported from the root extract of the plant ${ }^{9,12}$. In Western Ghats region of India, the decoctions and extracts of the roots of this plant are effective remedies in the management and/or control of convulsions and epilepsy. However, no scientific data are available to validate the folklore claim. The aim of the present study was, therefore, to evaluate the anticonvulsant potential of the ethanol extract of the roots of
C. carandas in experimental animal models, with a view to providing a pharmacological justification (or otherwise) for the ethnomedical use of the plant's root in the management of convulsions and epilepsy in some rural communities of India.

\section{Materials and Methods}

\section{Plant material}

The roots of $C$. carandas were collected from Udupi, Karnataka, during April 2006. It was authenticated by Dr. Gopalakrishna Bhat, Department of Botany, Poorna Prajna College, Udupi, Karnataka, India. A voucher specimen (no. 105a) is deposited in the herbarium of our institute.

\section{Preparation of extract}

Fresh roots were collected and dried in the shade. The shade-dried roots of the plant (500 $\mathrm{gm}$ ) were powdered and soaked in $1.5 \mathrm{~L}$ of $95 \%$ ethyl alcohol for 4 days and the liquid extract was decanted. The process of soaking and decanting was repeated for 4 times with fresh solvent. The solvent of the total liquid extract was evaporated by distillation to a concentrate over a water bath to a syrupy consistency and then evaporated to dryness under vacuum to give the dry extract $(16 \%$ $\mathrm{w} / \mathrm{w}$ yield). The extract was stored at $4{ }^{\circ} \mathrm{C}$ until used as a suspension with $2 \%$ Tween $80 /$ saline.

\section{Experimental animals}

Swiss mice of either sex, 8-10 weeks old, weighing about 25-30 $\mathrm{g}$ were used in experiments. Animals were housed in polypropylene cages maintained under standard condition (12 hours light / dark cycle; $25 \pm 3{ }^{0} \mathrm{C}, 45-65 \%$ humidity) and had free access to standard rat feed (Hindustan Liver Ltd., India) and water ad libitum. All the animals were acclimatized to laboratory condition for a week before commencement of experiment. All experimental protocols were reviewed and accepted by the Institutional 
Animal Ethical Committee (IAEC) prior to the initiation of the experiment.

\section{Drugs and chemicals}

Pentylenetetrazole (PTZ; Sigma Chemical Co.), picrotoxin (PC; Sigma Chemical Co.), $N$ methyl-dl-aspartic acid (NMDLA; Sigma Chemical Co.), phenobarbitone (PHNB; Phenetone, Cipla, India) and 5,5diphenylhydantoin sodium salt (Phenytoin, PHNY; Sigma Chemical Co.) were all dissolved in physiological saline. +Bicuculline (BC; Sigma Chemical Co.) was suspended in $0.5 \mathrm{ml}$ of Tween 80 (Ranbaxy Laboratories Ltd) and adjusted to an appropriate volume with physiological saline. Diazepam (DZP; Calmpose, Ranbaxy Pharma, India) was also suspended in a minimum amount of polyethylene glycol 400 (Ranbaxy Laboratories Ltd) and adjusted to an appropriate volume with physiological saline. Fresh drug solutions were prepared on each day of the experiments. Drugs were administered intraperitoneally (i.p.) in a volume of $1 \mathrm{ml} / 100 \mathrm{~g}$ of animal. Control animals received equal volume of injections of the appropriate vehicle. The doses and pretreatment times of the extract of the roots of $C$. carandas and the standard antiepileptic drugs used were obtained from preliminary studies in our laboratory. The pretreatment dose and the times following the administration of either pentylenetetrazole (90 $\mathrm{mg} / \mathrm{kg}$, i.p.), picrotoxin (10 $\mathrm{mg} / \mathrm{kg}$, i.p.), bicuculline $(40 \mathrm{mg} / \mathrm{kg}$, i.p.) or NMDLA (400 $\mathrm{mg} / \mathrm{kg}$, i.p.) were C. carandas extract $(100$, 200 and $400 \mathrm{mg} / \mathrm{kg}$, i.p., $30 \mathrm{~min}$ ), diazepam (0.5 mg/kg, i.p., $20 \mathrm{~min}$ ), phenobarbitone (10 $\mathrm{mg} / \mathrm{kg}$, i.p., $10 \mathrm{~min})$ and phenytoin $(25 \mathrm{mg} / \mathrm{kg}$, i.p., $20 \mathrm{~min})$.

\section{Phytochemical screening}

The freshly prepared extract of the roots of $C$. carandas (ERCC) was subjected to phytochemical screening tests for the detection of various constituents ${ }^{13}$.

\section{Acute toxicity study}

The toxicity study was determined in mice by modified method of Lorke ${ }^{14}$. Mice fasted for 16 $\mathrm{h}$ were randomly divided into groups of 10 mice per group and were administered i.p. with the extract in doses ranging from 100$2000 \mathrm{mg} / \mathrm{kg}$. The procedure described in detail earlier by Ojewole was followed for the determination of the acute toxicity of the plant extract ${ }^{15}$.

\section{Anticonvulsant activity}

\section{Electrically-induced seizures}

In the electrically-induced seizure experiment, the maximal electroshock (MES) method described previously by Swinyard was employed $^{16}$. In brief, tonic convulsions of the hind extremities of the mice were induced by passing alternating electrical current of $50 \mathrm{~Hz}$ and $150 \mathrm{~mA}$ for $0.2 \mathrm{sec}$ through corneal electrodes. The animals were divided randomly into 7 groups containing 8 animals each. Group I served as vehicle control group treated with Tween-80 (0.25 ml, i.p., $30 \mathrm{~min})$; groups II, III and IV served as test groups treated with the extract $(100,200$ and 400 $\mathrm{mg} / \mathrm{kg}$, i.p., $30 \mathrm{~min}$ ), respectively, and groups V, VI and VII served as reference groups treated with diazepam $(0.5 \mathrm{mg} / \mathrm{kg}$, i.p., $20 \mathrm{~min})$, phenobarbitone (10 mg/kg, i.p., $10 \mathrm{~min})$ and phenytoin (25 mg/kg, i.p., $20 \mathrm{~min}$ ), respectively, prior to the induction of convulsion. The number of animals protected from hind limb tonic extension seizure (HLTE) and the time spent in this position were determined for each dose group.

\section{Chemically-induced seizures}

The modified method of Vellucci and Webster $^{17}$ was used to assess the anticonvulsant effect of the extract. The animals were divided randomly into 7 groups containing 8 animals each and they were treated as described for electrically-induced seizure tests. Seizures were induced in mice with standard convulsing agents, 
pentylenetetrazole (PTZ), picrotoxin (PC), bicuculline $(\mathrm{BC})$ or N-methyl-dl-aspartic acid (NMDLA) and the animals were observed for 30 min for tonic convulsion episode. Hind limb extension was taken as tonic convulsion. The onset of tonic convulsion and the number of animals convulsing or not convulsing within the observation period were noted. The ability of the plant extract to prevent or delay the onset of the hind limb extension exhibited by the animals was taken as an indication of anticonvulsant activity ${ }^{18}$.

\section{Statistical analysis}

The results of the duration of seizures in electrically-induced seizures and onset of seizures in chemically-induced seizures were analyzed using the paired Student's t-test, while the proportion of animals that exhibited tonic seizures in both cases was analyzed using Chi-squared test. A $p$ value of $<0.05$ was considered as statistically significant.

\section{Results}

\section{Phytochemical screening}

Phytochemical screening of the extract (ERCC) showed that the crude extract contained small quantities of alkaloids, flavonoids, saponins and large amounts of cardiac glycosides, triterpenoids, phenolic compounds and tannins.

\section{Acute toxicity study}

There was no mortality amongst the graded dose groups of mice up to a dose of 2000 $\mathrm{mg} / \mathrm{kg}$ for duration of $72 \mathrm{~h}$. This finding probably suggests that the ethanol extract is relatively safe or non-toxic in mice at the doses used for this study.

\section{Anticonvulsant assessment}

Maximal electroshock produced hind limb tonic extension seizures (HLTE) in all the animals used. The vehicle-treated mice showed tonic hind limb extension for a duration of $15.15 \pm 0.19 \mathrm{sec}$. ERCC (100 $\mathrm{mg} / \mathrm{kg}$ ) significantly reduced the latency, but did not alter the incidence of seizures elicited by maximal electroshock to any significant extent. ERCC at doses of 200 and $400 \mathrm{mg} / \mathrm{kg}$, respectively, protected $25 \%$ and $50 \%$ of mice and significantly reduced the duration of the seizures. The standard antiepileptic drug, diazepam protected $50 \%$ of mice against seizures and significantly reduced the duration of the seizures, while phenobarbitone significantly protected $87.5 \%$ of mice and reduced the duration of the seizures. However, phenytoin completely inhibited the MES-induced tonic seizures in all the animals used (Table 1).

Pentylenetetrazole produced tonic seizures in all the animals used. A dose of $100 \mathrm{mg} / \mathrm{kg}$ of ERCC protected $25 \%$ of animals against seizures and did not affect the onset of seizures to any significant extent. ERCC, in doses of 200 and $400 \mathrm{mg} / \mathrm{kg}$, respectively, protected $50 \%$ and $62.5 \%$ of mice against seizures, and significantly delayed the latency of the seizures. The standard antiepileptic drugs, diazepam and phenobarbitone, completely protected the animals from seizures. Phenytoin neither affected the onset nor the incidence of convulsion to any significant extent, as shown in Table 2.

Picrotoxin produced tonic seizures in all the animals. ERCC (200 and $400 \mathrm{mg} / \mathrm{kg}$ ) did not affect the incidence of seizures, but significantly prolonged latency of seizures. The standard antiepileptic drugs, diazepam significantly protected the animals from convulsions and prolonged the latency of seizures, while phenobarbitone did not alter the incidence, but significantly delayed the onset of seizures. Phenytoin neither affected the onset nor the incidence of convulsion to any significant extent (Table 3).

Bicuculline induced tonic seizures in all the mice used. However, all the doses of ERCC $(100,200$ and $400 \mathrm{mg} / \mathrm{kg}$ ) did not alter the incidence of seizures significantly. Besides, $400 \mathrm{mg} / \mathrm{kg}$ of ERCC significantly shortened 
Table 1: Effect of ethanol extract of the roots of $C$. carandas (ERCC) on maximal electroshock (MES) induced seizures in mice

\begin{tabular}{cccccccc}
\hline \multicolumn{3}{c}{ Dose $(\mathrm{mg} / \mathrm{kg})$} & & & $\begin{array}{c}\text { No. of animals } \\
\text { convulsed/ } \\
\text { No. used }\end{array}$ & $\begin{array}{c}\text { Animals } \\
\text { protected } \\
(\%)\end{array}$ & $\begin{array}{c}\text { Duration of } \\
\text { HLTE (sec) } \\
\text { Mean } \pm \text { SEM }\end{array}$ \\
\hline $0.25 \mathrm{ml}$ & ERCC & DZP & PHNB & PHNY & & & \\
- & 100 & - & - & - & $8 / 8$ & 0 & $15.15 \pm 0.19$ \\
- & 200 & - & - & - & $8 / 8$ & 0 & $12.93 \pm 0.15^{\star}$ \\
- & 400 & - & - & - & $6 / 8$ & 25 & $9.62 \pm 0.13^{\star *}$ \\
- & - & 0.5 & - & - & $4 / 8$ & 50 & $6.73 \pm 1.03^{\star *}$ \\
- & - & - & 10 & - & $4 / 8$ & 50 & $5.06 \pm 0.93^{\star *}$ \\
- & - & - & - & 25 & $1 / 8^{\dagger}$ & 87.5 & $4.66 \pm 0.23^{* *}$ \\
\hline
\end{tabular}

${ }^{\star} p<0.05,{ }^{* *} p<0.01$, vs. Tween 80 treated group $(0.25 \mathrm{ml}$, i.p.); Student's t-test.

${ }^{\dagger} p<0.01,{ }^{\dagger \dagger} p<0.001$ vs. Tween 80 treated group $(0.25 \mathrm{ml}$, i.p.); Chi-squared test.

DZP- Diazepam; PHNB- Phenobarbitone; PHNY- Phenytoin; HLTE- Hind limb tonic extension seizure.

Table 2: Effect of ethanol extract of the roots of $C$. carandas (ERCC) on pentylenetetrazole (PTZ) induced seizures in mice

\begin{tabular}{ccccccccc}
\hline & \multicolumn{3}{c}{ Dose $(\mathrm{mg} / \mathrm{kg})$} & & & $\begin{array}{c}\text { No. of } \\
\text { animals } \\
\text { convulsed/ } \\
\text { No. used }\end{array}$ & $\begin{array}{c}\text { Animals } \\
\text { protected } \\
(\%)\end{array}$ & $\begin{array}{c}\text { Latency of } \\
\text { tonic convulsion } \\
\text { (min) } \\
\text { Mean } \pm \text { SEM }\end{array}$ \\
\hline 90 & $\begin{array}{c}\text { Tween } \\
80\end{array}$ & ERCC & DZP & PHNB & PHNY & & & \\
90 & $0.25 \mathrm{ml}$ & - & - & - & - & $8 / 8$ & 0 & $6.34 \pm 0.95$ \\
90 & - & 100 & - & - & - & $6 / 8$ & 25 & $9.61 \pm 1.78$ \\
90 & - & 400 & - & - & - & $4 / 8$ & 50 & $12.29 \pm 2.26^{*}$ \\
90 & - & - & 0.5 & - & - & $3 / 8$ & 62.5 & $16.20 \pm 1.63^{* *}$ \\
90 & - & - & - & 10 & - & $0 / 8^{\dagger}$ & 100 & 0 \\
90 & - & - & - & - & 25 & $0 / 8^{\dagger}$ & 100 & 0 \\
\hline
\end{tabular}

${ }^{*} p<0.05,{ }^{* \star} p<0.025$ vs. Tween 80 treated group $(0.25 \mathrm{ml}$, i.p. $)$; Student's t-test.

$+p<0.001$ vs. Tween 80 treated group $(0.25 \mathrm{ml}$, i.p.); Chi-squared test.

DZP- Diazepam; PHNB- Phenobarbitone; PHNY- Phenytoin.

Table 3: Effect of ethanol extract of the roots of $C$. carandas (ERCC) on picrotoxin (PC) - induced seizures in mice

\begin{tabular}{ccccccccc}
\hline & \multicolumn{3}{c}{ Dose $(\mathrm{mg} / \mathrm{kg})$} & & & $\begin{array}{c}\text { No. of animals } \\
\text { convulsed/ No. } \\
\text { used }\end{array}$ & $\begin{array}{c}\text { Animals } \\
\text { protected } \\
(\%)\end{array}$ & $\begin{array}{c}\text { Latency of } \\
\text { tonic convulsion } \\
\text { (min) } \\
\text { Mean } \pm \text { SEM }\end{array}$ \\
\hline 10 & $0.25 \mathrm{ml}$ & - & - & - & - & $8 / 8$ & 0 & $14.15 \pm 0.60$ \\
10 & - & 100 & - & - & - & $8 / 8$ & 0 & $15.39 \pm 0.76$ \\
10 & - & 200 & - & - & - & $8 / 8$ & 0 & $17.05 \pm 0.97^{*}$ \\
10 & - & 400 & - & - & - & $8 / 8$ & 0 & $19.32 \pm 1.30^{*}$ \\
10 & - & - & 0.5 & - & - & $1 / 8^{\dagger}$ & 87.5 & $22.60 \pm 1.70^{* *}$ \\
10 & - & - & - & 10 & - & $8 / 8$ & 0 & $24.36 \pm 1.35^{* *}$ \\
10 & - & - & - & - & 25 & $8 / 8$ & 0 & $14.60 \pm 1.91$ \\
\hline
\end{tabular}

${ }^{*} p<0.05,{ }^{* *} p<0.025$ vs. Tween 80 treated group $(0.25 \mathrm{ml}$, i.p. $)$; Student's t-test.

${ }^{\dagger} p<0.01$ vs. Tween 80 treated group $(0.25 \mathrm{ml}$, i.p.); Chi-squared test.

DZP- Diazepam; PHNB- Phenobarbitone; PHNY- Phenytoin. 
the latency of seizures in mice. The standard antiepileptic drugs, diazepam and phenobarbitone, completely protected the animals from seizures. Phenytoin neither affected the onset nor the incidence of convulsion to any significant extent (Table 4).

NMDLA induced tonic seizures in all the mice used. ERCC (200 and $400 \mathrm{mg} / \mathrm{kg}$ ) significantly prolonged the latency of the seizures. However, only the higher dose $(400 \mathrm{mg} / \mathrm{kg}$ ) protected $25 \%$ of the animals from convulsions. The standard antiepileptic drugs, diazepam, phenobarbitone and phenytoin did not significantly affect the incidence or the onset of seizures (see Table 5).

\section{Discussion}

The results of the present study indicate that ethanol extract of the roots of $C$. carandas (ERCC) possesses anticonvulsant activity in mice. GABA is the major inhibitory neurotransmitter in the brain while glutamic acid is an excitatory neurotransmitter in the brain. The inhibition of GABA neurotransmitter and the enhancement of the action of glutamic acid have been shown to be the underlying factors in epilepsy ${ }^{19,20}$. Our study shows that the ethanol extract of the roots of $C$. carandas protected some of the animals against seizures induced by maximal electroshock, pentylenetetrazole, picrotoxin and NMDLA and also delayed the latency of the seizures.

In the present study maximal electroshock produced seizures in all the animals used. Antiepileptic drugs that block MES-induced tonic extension are known to act by blocking seizure spread $^{21}$. Moreover, drugs that inhibit voltage-dependent $\mathrm{Na}+$ channels, such as phenytoin can prevent MES-induced tonic extension $^{21,22}$. However, phenobarbitone is as effective against electrically-induced convulsion as it is against pentylenetetrazoleinduced convulsions in mice and phenobarbitone is known to reduce the electrical activity of neurons within a chemically-induced epileptic focus in the cortex, while diazepam does not suppress the focal activity but prevents it from spreading ${ }^{23,24}$. Diazepam had anticonvulsant effect on both PTZ-induced seizures and maximal electroshock-induced seizures, in which diazepam effect on the former $(100 \%$ protection) is better than the latter $(50 \%$ protection). This is consistent with the report that benzodiazepine (BDZ) agonists such as diazepam, clonazepam, etc, are more potent in the prevention of PTZ-induced seizures than in that of MES-induced tonic seizures ${ }^{25}$.

Pentylenetetrazole induced seizures in all the mice used. Pentylenetetrazole may elicit seizures by inhibiting gabaergic mechanisms ${ }^{26}$. Standard antiepileptic drugs, diazepam and phenobarbitone, are believed to produce their effects by enhancing GABAmediated inhibition in the brain $^{20}$. It is, therefore, possible that the anticonvulsant effects shown in this study by the drugs against seizures produced by PTZ might be due to the activation of GABA neurotransmission. Since the extract similarly antagonized seizures elicited by pentylenetetrazole in mice, it is probable, therefore, that it may also be exerting its anticonvulsant effects by affecting gabaergic mechanisms.

Picrotoxin also produced seizures in all the mice used. Picrotoxin is known to elicit seizures, by antagonizing the effect of GABA via blocking of the chloride channels linked to $\mathrm{GABA}_{\mathrm{A}}$-receptor ${ }^{19,20}$. In this study, diazepam and phenobarbitone were shown to antagonize the effect of picrotoxin while the extract was also shown to delay the latency of picrotoxin-induced seizures, suggesting that the extract may be affecting gabaergic mechanisms, probably by opening the chloride channels associated with GABAreceptors.

Bicuculline is a selective antagonist of GABA at the $\mathrm{GABA}_{A}$-receptors ${ }^{20}$. The fact that the extract did not affect the seizures induced by bicuculline, suggests that its effect on gabaergic mechanisms may not be via the stimulation of $\mathrm{GABA}_{\mathrm{A}}$-receptors. NMDLA was 
Table 4: Effect of ethanol extract of the roots of $C$. carandas (ERCC) on bicuculline (BC) - induced seizures in mice

\begin{tabular}{ccccccccc}
\hline & \multicolumn{3}{c}{ Dose $(\mathrm{mg} / \mathrm{kg})$} & & & $\begin{array}{c}\text { No. of } \\
\text { animals } \\
\text { convulsed/ } \\
\text { No. used }\end{array}$ & $\begin{array}{c}\text { Animals } \\
\text { protected } \\
(\%)\end{array}$ & $\begin{array}{c}\text { Latency of } \\
\text { tonic convulsion } \\
\text { (min) } \\
\text { Mean } \pm \text { SEM }\end{array}$ \\
\hline 40 & $\begin{array}{c}\text { Tween } \\
80\end{array}$ & ERCC & DZP & PHNB & PHNY & & \\
40 & $-25 \mathrm{ml}$ & - & - & - & - & $8 / 8$ & 0 & $10.80 \pm 0.49$ \\
40 & - & 100 & - & - & - & $8 / 8$ & 0 & $9.78 \pm 0.71$ \\
40 & - & 400 & - & - & - & $8 / 8$ & 0 & $10.28 \pm 0.74$ \\
40 & - & - & 0.5 & - & - & $8 / 8$ & 0 & $5.93 \pm 0.33^{*}$ \\
40 & - & - & - & 10 & - & $0 / 8^{\dagger}$ & 100 & 0 \\
40 & - & - & - & - & 25 & $0 / 8^{\dagger}$ & 100 & 0 \\
\hline
\end{tabular}

${ }^{*} p<0.025$, vs. Tween 80 treated group $(0.25 \mathrm{ml}$, i.p. $)$; Student's t-test.

${ }^{\dagger} p<0.001$ vs. Tween 80 treated group ( $0.25 \mathrm{ml}$, i.p.); Chi-squared test.

DZP- Diazepam; PHNB- Phenobarbitone; PHNY- Phenytoin.

Table 5: Effect of ethanol extract of the roots of $C$. carandas (ERCC) on N-methyl-dl-aspartic acid (NMDLA) - induced seizures in mice

\begin{tabular}{ccccccccc}
\hline NMDLA & $\begin{array}{c}\text { Tween } \\
80\end{array}$ & ERCC & DZP & PHNB & PHNY & $\begin{array}{c}\text { No. of } \\
\text { animals } \\
\text { convulsed/ } \\
\text { No. used }\end{array}$ & $\begin{array}{c}\text { Animals } \\
\text { protected } \\
(\%)\end{array}$ & $\begin{array}{c}\text { Latency of } \\
\text { tonic } \\
\text { convulsion } \\
\text { (min) } \\
\text { Mean } \pm \text { SEM }\end{array}$ \\
\hline 400 & $0.25 \mathrm{ml}$ & - & - & - & - & $8 / 8$ & 0 & $3.56 \pm 0.54$ \\
400 & - & 100 & - & - & - & $8 / 8$ & 0 & $4.58 \pm 0.36$ \\
400 & - & 200 & - & - & - & $8 / 8$ & 0 & $5.79 \pm 0.39^{*}$ \\
400 & - & 400 & - & - & - & $6 / 8$ & 25 & $8.75 \pm 1.41^{*}$ \\
400 & - & - & 0.5 & - & - & $8 / 8$ & 0 & $4.02 \pm 0.53$ \\
400 & - & - & - & 10 & - & $8 / 8$ & 0 & $2.35 \pm 0.29$ \\
400 & - & - & - & - & 25 & $8 / 8$ & 0 & $3.93 \pm 0.43$ \\
\hline
\end{tabular}

${ }^{*} p<0.05$ vs. Tween 80 treated group (0.25 ml, i.p.); Student's t-test.

DZP- Diazepam; PHNB- Phenobarbitone; PHNY- Phenytoin.

also shown to elicit seizures in all the mice used. NMDLA, a specific agonist at the NMDA receptors, mimics the action of glutamic acid and thus induces seizures by enhancing the glutaminergic system ${ }^{20}$. It is not surprising that the standard drugs, diazepam and phenobarbitone, did not alter NMDLA-induced seizures to any significant extent. In this study, the extract was shown to delay the latency of seizures induced by NMDLA. It may, therefore, be exerting its anticonvulsant effect partly by affecting glutaminergic mechanisms.
The phytochemical screening of the extract revealed the presence of small quantities of alkaloids, flavonoids, saponins and large amounts of cardiac glycosides, triterpenoids, phenolic compounds and tannins. Based on the present state of knowledge of the chemical constituents of the extract, it is not possible to attribute with certainty its anticonvulsant effect to one or several active principles among those detected in the screening. However, triterpenic steroids and triterpenoidal saponins are reported to possess anticonvulsant activity in some experimental seizure models such as MES and $\mathrm{PTZ}^{27,28}$. Some alkaloids, monoterpenes, 
flavonoids also have protective effects against PTZ, picrotoxin and NMDLA-induced convulsions ${ }^{29-32}$. It is worthwhile to isolate the bioactive principles, which are responsible for these activities; the process has commenced in our laboratory. These findings justify the traditional use of this plant in the control and/or treatment of convulsions and epilepsy.

\section{Conclusion}

It can be concluded from the study that the anticonvulsant effects of the ethanolic root extract of $C$. carandas may be via non-specific mechanisms. However, extensive studies are needed to evaluate the precise mechanism(s), active principles, and the safety profile of the plant as a medicinal remedy for convulsive disorders.

\section{Acknowledgement}

The authors are thankful to the authorities of A. Shama Rao Foundation Mangalore, Karnataka, India and Nitte Education Trust Mangalore, Karnataka, India for providing the required facilities.

\section{References}

1. Sander JWAS, Shorvon SD. Epidemiology of epilepsies. I Neurol Neurosurg Psychiatry 1996; 61: 433-443.

2. Smith MC, Bleck TP. Convulsive Disorders: toxicity of anticonvulsants. Clin Neuropharmacol 1991; 14: $97-115$.

3. Mattson RH. Efficacy and adverse effects of established and new antiepileptic drugs. Epilepsia 1995; 36 (2): S13-S26.

4. SamrJn EB, van Duijn CM, Koch S, Hiidesmaa VK, Klepel $H$, Bardy AH, Mannagetta GB, Deichl AW, Gaily E, Granstron ML, Meinardi $A H$, Grobbee DE, Hofman A, Janz D, Lindhout $D$. Maternal use of antiepileptic drugs and the risk of major congenital malformations : a joint European prospective study of human teratogenesis associated with material epilepsy. Epilepsia 1997; 38: 981.

5. Akerele O. Medicinal plants and primary health care: an agenda for action. Fitoterapia, LIX, 1988; 355-363.

6. Farnsworth NR. Screening plants for new medicines. In: Wilson EO, Ed, Biodiversity, Part II. National Academy Press, Washington, 1989, pp 83-97.
7. Raza M, Choudary MI, Atta-ur-Rahman. Anticonvulsant medicinal plants. In: Atta-urRahman (Ed.). Studies in Natural Product Chemistry, Vol 22, Elsevier Science Publishers, Netherlands, 1999, pp 507-553.

8. Kirtikar KR, Basu BD. Indian Medicinal Plants. Lalit Mohan Basu, Allahabad. Vol. II, 2003, pp 15461549.

9. Dhawan BN, Patnaik GK. Investigation on some new cardio-active glycosides. Indian Drugs 1985; 22(6): 285-290.

10. Rajasekaran A, Jeyasudha V, Kalpana B, Jayakar B. Preliminary phytochemical and antipyretic evaluation of Carissa carandas. Indian J Nat Prod 1999; 15(1): 27-29.

11. Taylor RSL, Hudson JB, Manandhar NP, Tower GHN. Antiviral activities of medicinal plant of Southern Nepal. J Ethnopharmacol 1996; 53(2): 97-104.

12. Rastogi RC, Vohra MM, Rastogi RP, Dhar ML. Studies on Carissa carandas Linn. Part I. Isolation of the cardiac active principles. Indian J Chem 1966; 4: 132.

13. Harbone JB. Phytochemical methods. A Guide to Modern Techniques of Plant Analysis. $2^{\text {nd }} \mathrm{Ed}$, Chapman and Hall, London, 1984, pp 84-274.

14. Lorke D. A new approach to practical acute toxicity testing. Arch Toxicol 1983; 54: 275-287.

15. Ojewole JAO. Antinociceptive, anti-inflammatory and antidiabetic properties of Hypoxis hemerocallidea Fisch. and C. A. Mey. (Hypoxidaceae) corm ['African Potato'] aqueous extract in mice and rats. J Ethnopharmacol 2006; 103: 126-134.

16. Swinyard EA. Laboratory evaluation of antiepileptic drugs. Review of Laboratory methods. Epilepsia 1969; 10: 107-119.

17. Vellucci SV, Webster RA. Antagonism of caffeineinduced seizures in mice by Ro 15-1788. Eur J Pharmacol 1984; 97: 289-295.

18. Amabeoku GJ, Chikuni O. Cimetidine-induced seizures in mice. Biochem Pharmacol 1993; 46 (12): 2171-2175.

19. Westmoreland BF, Benarroch EE, Dube JR, Regan TJ, Sandok BA. Medicinal neurosciences, Rochester: Margo Foundation, 1994, pp 307312.

20. Rang HP, Dale MM, Ritter JM, Moore PK. Pharmacology 5th ed. India: Churchill Livingstone, 2005 pp 456-473.

21. Rogawski MA, Porter RJ. Antiepileptic drugs: pharmacological mechanisms and clinical efficacy with consideration of promising development stage compounds, Pharmacol Rev 1990; 42: 223-286.

22. MacDonald RL, Kelly KM. Antiepileptic drug mechanisms of action. Epilepsia 1995; 36: S2S12.

23. Levy RH, Mattson RH, Meldrum BS, Driefuss FE, Penry JK. Antiepileptic drug. $4^{\text {th }}$ Ed, Raven Press, New York, 1995.

24. Meldrum BS. Update on the mechanism of action of antiepileptic drugs. Epilepsia 1996; 37: S4-S11. 
25. Krall RL, Penry JK, White BG, Kupferberg HJ, Swinyard EA. Antiepileptic drug development: II. Anticonvulsant drug screening. Epilepsia 1978; 19: 409-428.

26. De Sarro A, Cecchetti V, Fravoloni V, Naccari $F$ Tabarrinia O, De Sarro G. Effects of novel6desfluoroquirolones and classic quinolones on pentylenetetrazole-induced seizure in mice. Antimicrob Agents Chemother 1999; 43: 17291736.

27. Kasture VS, Kasture SB, Chopde CT. Anticonvulsive activity of Butea monosperma flowers in laboratory animals. Pharmacol Biochem Behav 2002; 72: 965-972.

28. Chauhan AK, Dobhal MP, Joshio BC. A review of medicinal plant showing anticonvulsant activity. J Ethnopharmacol 1988; 22: 11-23.
29. Librowski T, Czarnecki R, Mendyk A, Jastrzebska M. Influence of new monoterpenes homologues of GABA on the central nervous system activity in mice. Polish J Pharmacol 2000; 52: 317-321.

30. Brum LF, Elisabetsky E, Souza D. Effects of linalool on [(3) H] MK801 and [(3) H] muscimol binding in mouse cortical membranes. Phytother Res 2001; 15: 422-425.

31. Santos Dos Jr. JG. , Blanco MM, Monte Do FHM, Russi M, Lanziotti VMNB, Lanziotti, LKAM Leal, Cunha GM. Sedative and anticonvulsant effects of hydroalcoholic extracts of Equisetum arvense. Fitoterapia 2005; 76(6): 508-513.

32. Johnston GAR, Beart PM. Flavonoids: Some of the wisdom of sage? Br J Pharmacol 2004; 142: 809-810. 